\title{
Breaking the Bond: Primary Markets and Carbon-Intensive Financing
}

\section{Christian Wilson \& Ben Caldecott}

\section{1}

Oxford Sustainable Finance Programme, Smith School of Enterprise and the Environment, University of Oxford | Working Paper No. 21-05

ISSN 2732-4214 (Online)

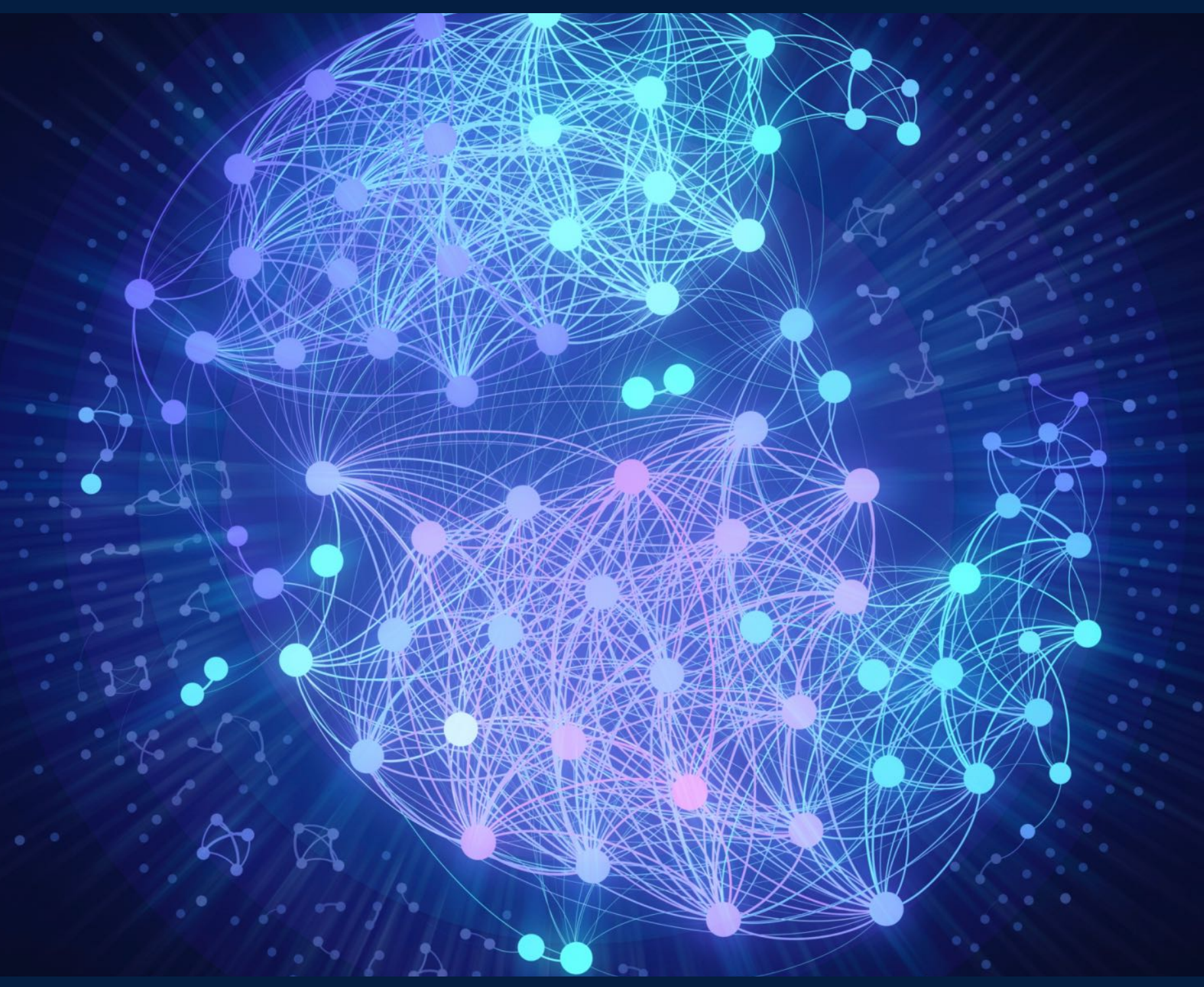


Aligning finance with sustainability is a necessary condition for tackling the environmental and social challenges facing humanity. It is also necessary for financial institutions and the broader financial system to manage the risks and capture the opportunities associated with the transition to global environmental sustainability.

The University of Oxford has world-leading researchers and research capabilities relevant to understanding these challenges and opportunities. The Oxford Sustainable Finance Programme (OxSFP) is the focal point for these activities and is situated in the University's Smith School of Enterprise and the Environment. OxSFP is a multidisciplinary research centre working to be the world's best place for research and teaching on sustainable finance and investment.

OxSFP is based in one of the world's great universities and the oldest university in the Englishspeaking world. We work with leading practitioners from across the investment chain (including actuaries, asset owners, asset managers, accountants, banks, data providers, investment consultants, lawyers, ratings agencies, stock exchanges), with firms and their management, and with experts from a wide range of related subject areas (including finance, economics, management, geography, data science, anthropology, climate science, law, area studies, psychology) within the University of Oxford and beyond. Since our foundation we have made significant and sustained contributions to the field, including in some of the following areas:

- Developing the concept of "stranded assets", now a core element of the theory and practice of sustainable finance.

- Contributions to the theory and practice of measuring environmental risks and impacts via new forms of geospatial data and analysis, including introducing the idea and importance of "spatial finance" and "asset-level data".

- Shaping the theory and practice of supervision as it relates to sustainability by working with the Bank of England, the central banks' and supervisors' Network for Greening the Financial System (NGFS), and the US Commodity Futures Trading Commission (CFTC), among others.

- Working with policymakers to design and implement policies to support sustainable finance, including through the UK Green Finance Taskforce, UK Green Finance Strategy, and the forthcoming UK Presidency of COP26.

- Nurturing the expansion of a rigorous academic community internationally by conceiving, founding, and co-chairing the Global Research Alliance for Sustainable Finance and Investment (GRASFI), an alliance of 28 global research universities promoting rigorous and impactful academic research on sustainable finance.

The Oxford Sustainable Finance Programme's founding Director is $\mathrm{Dr}$ Ben Caldecott. For more information please visit: https://www.smithschool.ox.ac.uk/research/sustainable-finance 


\section{Acknowledgements}

We would like to thank Dariusz Wójcik, Thom Wetzer, Ulf Erlandsson, and Ellen Quigley for discussions, engagement, and feedback on this topic, as well as the internal and external reviewers who provided many insightful comments.

\section{Suggested citation}

Wilson, C. \& Caldecott, B. (2021). Breaking the Bond: Primary Markets and Carbon-Intensive Financing. University of Oxford Smith School of Enterprise and the Environment Working Paper 21-05.

\section{Disclaimer}

The views expressed in this paper represent those of the authors and do not necessarily represent those of the Smith School or other institution or funder. The paper is intended to promote discussion and to provide public access to results emerging from our research. It may have been submitted for publication in academic journals. It has been reviewed by at least one internal referee before publication.

The Chancellor, Masters, and Scholars of the University of Oxford make no representations and provide no warranties in relation to any aspect of this publication, including regarding the advisability of investing in any particular company or investment fund or other vehicle. While we have obtained information believed to be reliable, neither the University, nor any of its employees, students, or appointees, shall be liable for any claims or losses of any nature in connection with information contained in this document, including but not limited to, lost profits or punitive or consequential damages. 


\title{
Breaking the Bond: Primary Markets and Carbon-Intensive Financing
}

\author{
Christian Wilson* \& Ben Caldecott* \\ *Oxford Sustainable Finance Programme, Smith School of Enterprise and the Environment, University of Oxford
}

\begin{abstract}
To align capital flows with the goals of the Paris Agreement, financial institutions must decarbonise primary market transactions, as these continue to provide new capital to the real economy that can create carbon lock-in and the risk of stranded assets. In this paper we define a new metric, Primary Market Carbon Exposure (PMCE), as the proportion of primary market transactions that occur in carbon-intensive sectors. We calculate PMCE for US corporate bond exchange-traded funds (ETFs) and find that these funds systematically partake in carbonintensive primary market transactions, with a PMCE of 14\% from 2015 to 2020, despite tracking indexes that rebalance monthly. High yield ETFs have a higher PMCE than investment grade ETFs and provide more financing to upstream oil \& gas. To avoid becoming capital providers of last resort for carbon-intensive sectors, ETF providers need to reduce PMCE in line with Paris Agreement carbon budgets. For policymakers, not only can passive funds contribute to carbon lock-in, but ETFs directly bought by central banks are financing carbon-intensive sectors. We demonstrate this for ETFs bought by the Federal Reserve in 2020.
\end{abstract}

Keywords: climate finance, passive investing, fossil fuels, divestment, capital flows 


\section{Introduction}

To date, financial institutions with over $\$ 70$ trillion have pledged net zero portfolios by 2050 , including the setting of interim 2030 targets that encompass all emission scopes (UNFCCC, 2021). Promoted by a growing recognition of climate-related risks and the role of finance in mitigating climate change, these commitments can contribute to the delivery of Article $2 \mathrm{c}$ of the Paris Agreement, namely for capital flows to be "consistent with a pathway towards low greenhouse gas emissions and climate-resilient development" (United Nations, 2015). Achieving this goal is critical for securing a low-carbon future. The IPCC estimate that limiting rises in global mean temperatures to $1.5^{\circ} \mathrm{C}$ above pre-industrial levels will require investment in energy systems alone of $\$ 2.4$ trn annually between 2016 and 2025 , equivalent to $2.5 \%$ of world GDP (IPCC, 2018).

Despite this challenge, when considering the climate alignment of financial portfolios, a significant amount of focus has been placed on stocks of capital rather than flows of capital. Examples of this include portfolio temperature alignment scores (CDP \& WWF, 2020) and portfolio carbon accounting (PCAF, 2020). Furthermore, metrics such as carbon intensity (Hunt \& Weber, 2019), shadow impact (Ritchie \& Dowlatabadi, 2014) and greenhouse gas exposure (Monasterolo, Battiston, Janetos, \& Zheng, 2017) do not explicitly account for capital flows. Recent consultations by the Taskforce for Climate-Related Disclosures on forward looking metrics (TCFD, 2020), the Net-Zero Asset Owner Alliance on a target setting protocol' (UNEP FI, 2020) and the Institutional Investor Group on Climate Change on net zero investing (IIGCC, 2020) also all appear to focus on total portfolio holdings rather than flows.

These methods provide useful insights, by, for example, tracking exposure to climate risks. Yet Climate Risk Management (CRM) and Alignment with Climate Outcomes (ACO) or climate "impact" - are not one and the same (Caldecott, 2020). A key transmission mechanism to drive ACO is through capital allocation, which can affect asset prices and the cost of capital faced by companies in the real economy (Caldecott, 2020; Caldecott, Harnett, Clark, \& Koskelo, 2021). Building on Brest and Born (2013) and Brest, Gilson, and Wolfson (2018), Kölbel, Heeb, Paetzold, and Busch (2020) define investor impact as "the change that investor activities achieve in company impact", and company impact as "the change that company activities achieve in social and environmental parameters". In this context, changes in the cost of capital can affect the ability of companies to finance operations and expand, both in low and high-carbon sectors, thereby linking investor impact with company impact. This transmission mechanism is the subject of this paper with respect to equity and bonds, which 
account for approximately $75 \%$ of institutional investor asset allocation (Mercer, 2020; Schroders, 2019).

At the portfolio level, capital allocation occurs in both primary and secondary markets. In the former, newly issued securities are purchased, while in the latter, trades occur in preexisting securities. Through secondary markets, transactions that alter portfolio holdings can improve CRM, by, for example, reducing the exposure of a portfolio to carbon-intensive sectors. However, even though secondary market transactions can affect asset prices, the impact of these changes on the real economy crystallises once companies raise new capital in primary marketsii. Therefore, for financial institutions interested in ACO as well as CRM, it is necessary to track and potentially change primary market portfolio flows. A focus on primary markets is especially relevant for policymakers, given the need to track low-carbon capital flows (Advisory Group on Finance for the UK's Climate Change Committee, 2020).

These arguments are often used to critique divestment, with decisions to sell liquid assets in secondary markets achieving little unless accompanied with publicity or used as a tool in effective engagement (Ansar, Caldecott, \& Tilbury, 2013; Quigley, Bugden, \& Odgers, 2020). However, as divestment reduces the exposure of a portfolio to carbon-intensive sectors, it will also reduce future carbon-intensive financing through primary markets.

To our knowledge, the Climate Policy Initiative's (CPI) proposed methodology for measuring climate alignment is the first applied only to primary markets (Rosane et al., 2020). This methodology assesses the alignment of new investments made over a period of time (Rosane et al., 2020). In other words, the focus is on capital flows rather than stocks. CPI link new investments with asset-level data to calculate the carbon intensity associated with transactions. To calculate alignment, this metric is compared to sectoral decarbonisation pathways that depend on technology and region. CPI provide an example applied to the power sector, using data from the Global Landscape of Climate Finance 2017.

In this paper, we instead track primary market financing in specific portfolios by measuring the proportion of total primary market transactions that occur in carbon-intensive sectors. This is defined as Primary Market Carbon Exposure (PMCE). PMCE allows carbonintensive financing to be tracked in the context of an overall portfolio, as well as capital allocation to different carbon-intensive sectors. For example, using PMCE, asset owners can track the proportion of financing allocated to oil \& gas exploration. However, the limitation of this approach is that it does not distinguish between leaders and laggards within carbon- 
intensive industries, and it is not forward-looking, as it doesn't account for a company's future CAPEX or transition plans.

Using this method, we draw attention to the importance of primary markets within the context of the low-carbon transition by applying the PMCE to fixed income ETFs. ETFs and other passive investment funds accounted for $30 \%$ of fixed income fund AUM in 2020, up from less than 5\% in 1995 (Anadu, Kruttli, McCabe, \& Osambela, 2020). We show that ETFs in our sample systematically partake in primary market transactions by investing in new issues before they are included in indexes that rebalance monthly. This demonstrates the flexibility of ETFs to deviate from the day-to-day constituents of indexes tracked. Within primary markets, the PMCE shows that these ETFs allocated $13.6 \%$ of transaction value to carbonintensive sectors from 2015 to 2020 . Given the rapid growth in passive investing, this dynamic could restrict the ability of financial markets to facilitate the low-carbon transition. At present, a small fraction of passive AUM is invested sustainably - less than $1 \%$ in the US (Morningstar, 2020). Therefore, if active investors reduce their carbon-intensive exposures, passive funds could step in as financiers of last resort by continuing to channel capital into carbon-intensive assets. This could limit the efficacy of sustainable finance policies focused on disclosure and the pricing of climate risks and impacts, with passive funds shown to reduce the cost of capital for issuers (Dannhauser, 2017; Dathan \& Davydenko, 2018)

To address this, ETF and passive fund providers should use their flexibility to finance only carbon-intensive companies with robust transition plans, while continuing to develop and promote low-carbon passive funds. Policymakers need to support the development of lowcarbon indexes and their use by asset owners. In addition, planned disclosure requirements for financial products and institutions can be extended to include metrics that capture primary market investments. Finally, central banks need to consider the climate impact of ETF purchases. As a case study, we show a PMCE of $13 \%$ for ETFs bought by the Federal Reserve in 2020.

This paper forms part of the Energy Transition Risk and Cost of Capital Project (ETRC), initiated by the Oxford Sustainable Finance Programme to examine the interplay between the energy transition and the cost of capital. It is structured as follows. First, we summarise the difference between primary markets and secondary markets and their ability to affect the cost and flow of capital. Second, we apply PMCE metric to corporate bond ETFs. Third, we outline the implications of a growing role of passive funds in primary markets, considering the policy implications and avenues for further research. 


\section{Primary Markets vs Secondary Markets}

As shown in Figure 1, primary market transactions occur when securities are newly issued, with capital flowing from the financial system to the real economy. Secondary market transactions occur in securities that already exist, with trades taking place between financial institutions. Therefore, to capture capital flows to the real economy, we focus on primary markets.

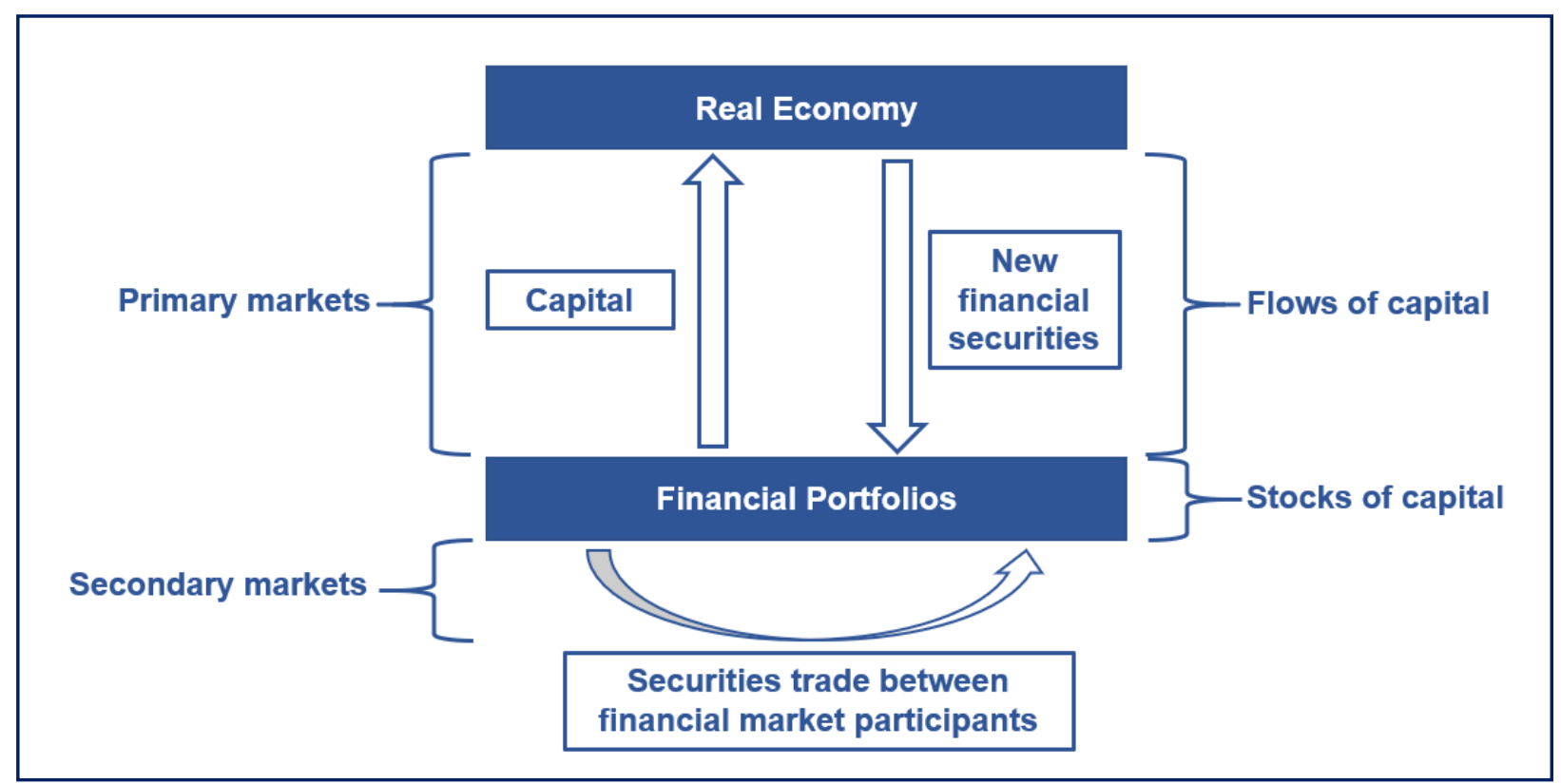

Figure 1. Stocks vs Flows of Capital.

\begin{tabular}{|l|l|l|}
\hline $\mathbf{2 0 1 9}$ & Equity & Corporate Debt \\
\hline Outstanding Market Value & $\$ 54.6$ trn & $\$ 9.6 \operatorname{trn}$ \\
\hline New Issuance & $\$ 0.2 \operatorname{trn}$ & $\$ 1.4 \operatorname{trn}$ \\
\hline$\%$ New Issuance & $0.7 \%$ & $14.8 \%$ \\
\hline
\end{tabular}

Table 1. US Capital Market Issuance 2019.

Source. Data from SIFMA (2020).

Depending on the asset class, the importance of primary markets varies. As shown in Table 1, US corporate bond issuance totalled \$1.4 trillion in 2019 compared to equity issuance of $\$ 0.2$ trillion, despite a market value approximately $82 \%$ smaller (SIFMA, 2020). From an asset-owner perspective, corporate debt is therefore crucial for the climate alignment of portfolio flows, with bonds accounting for a significant share of carbon-intensive financing in 


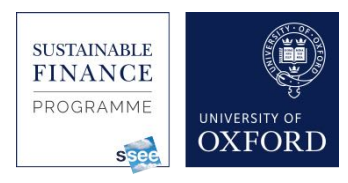

recent years (Figure 2). This has led academics to discuss "denying debt" to companies that are not Paris-aligned while continuing to engage robustly via equity holdings (Hoepner \& Schneider, 2020; Quigley, 2019). Hoepner and Schneider (2020) show that in 2021, €226 billion of carbon-intensive bonds will mature that may need refinancing, providing an opportunity for investors to demand improvements in climate performance or withhold capital.

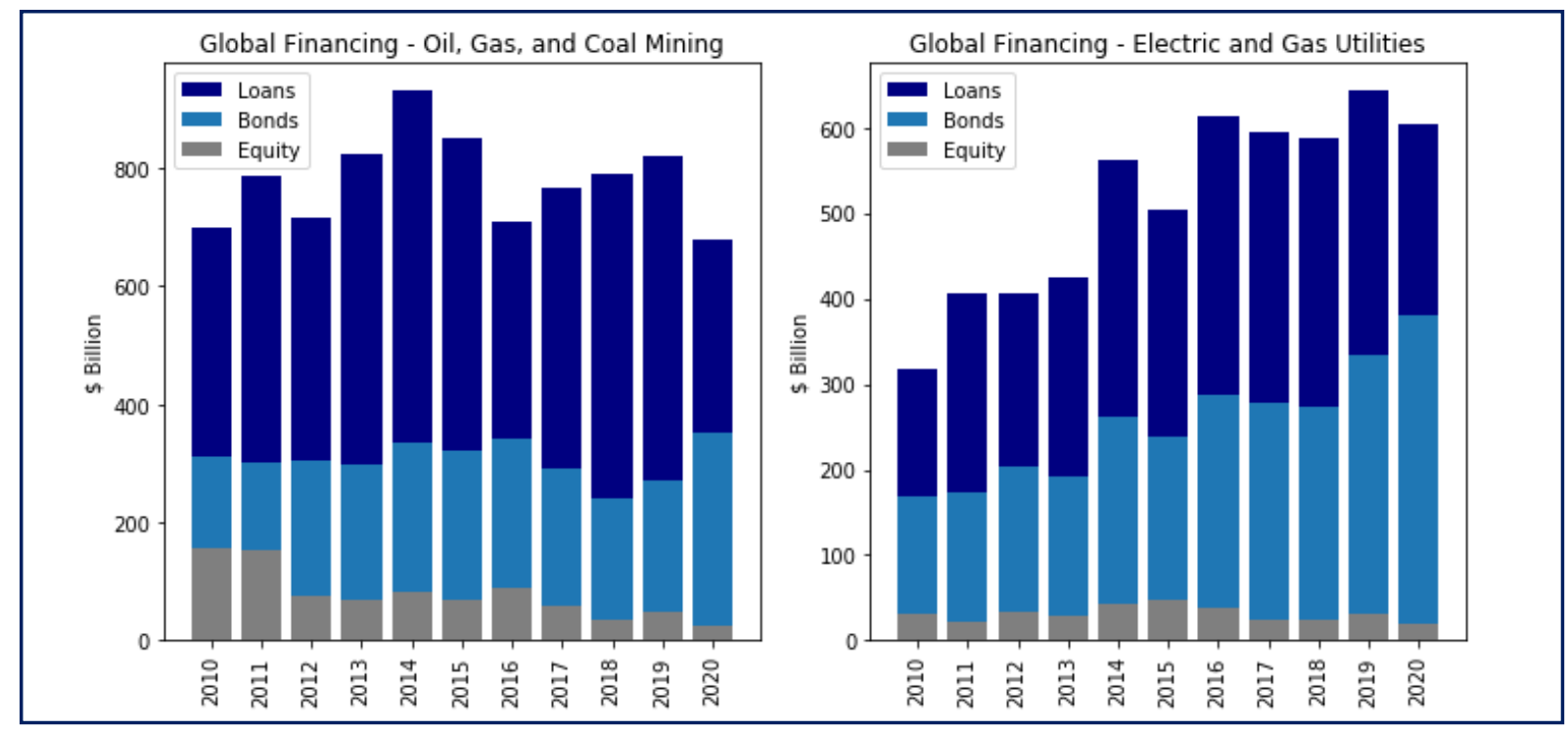

Figure 2. Global Carbon-Intensive Financing

Note. Transaction data is taken from Eikon in USD. Relevant transactions are identified using The Refinitiv Business Classifications (TRBC). Using the definition used by the Task Force on Climate-related Financial Disclosures (TCFD), carbon-intensive assets are classified as those in the energy and utilities sectors, excluding water and renewables.

\subsection{Asset Pricing and Sustainability}

In market equilibrium models, prices are set through the return expectations of investors, with all available information fully reflected in efficient markets (Gonedes, 1975). In Merton (1987), rather than assume the dissemination of public information is simultaneous, a model is developed with incomplete information, whereby investor knowledge of securities differs. In this instance, an expansion in the investor base reduces the cost of capital, as more investors become knowledgeable and therefore invest.

Developing this approach, Heinkel, Kraus, and Zechner (2001) swap heterogeneous information sets for heterogenous investor preferences, showing that the application of a sustainability screen lowers demand for affected securities and increases the cost of capital as the remaining investors take on more risk. Similarly, Gollier and Pouget (2014) and Luo 
and Balvers (2017) outline how changes in asset allocation to reflect social responsibility alter equilibrium prices and the cost of capital.

Equilibrium models incorporating sustainability can be also applied to primary markets. When issuing securities, investment banks adjust the cost of capital according to investor demand, aiming to find buyers while minimising costs for the issuing company (Lindvall, 1977). A change in investor preferences that underweights unsustainable companies can change these supply and demand dynamics, increasing the cost of capital (Beltratti, 2005).

\subsection{Capital Allocation and Impact}

In line with the demand dynamics outlined, Kölbel et al. (2020) identify capital allocation as a mechanism for investors to generate environmental impact, alongside shareholder engagement and indirect impacts. In this section, we review how capital allocation affects asset prices and the cost of capital in both primary and secondary markets.

In equity secondary markets, changes in capital allocation due to index construction positively affect the prices of index constituents due to higher demand from investors (Chang, Hong, \& Liskovich, 2015; Morch \& Yang, 2001). Similarly, in fixed income secondary markets, Ottonello (2018) show that an increase in index weights increase corporate bond prices.

In primary equity markets, high investor demand decreases the under-pricing of IPOs (Derrien, 2005) and follow-on offerings (Intintoli, Jategaonkar, \& Kahle, 2014), while in fixed income primary markets, higher demand reduces the cost of capital at issuance (Bessembinder, Jacobsen, Maxwell, \& Venkataraman, 2020; Dathan \& Davydenko, 2018). It is primary markets that determine the cost to companies when raising new capital to finance investment and operations, with research showing that a reduction in the cost of capital stimulates corporate investment (Drobetz, El Ghoul, Guedhami, \& Janzen, 2018; Frank \& Shen, 2016; Gilchrist \& Zakrajsek, 2007; Gilchrist \& Zakrajšek, 2012; Lin, Wang, Wang, \& Yang, 2018). Therefore, in the context of the low-carbon transition, changes in the cost of capital can facilitate low-carbon investment (Curtin et al., 2019; Ondraczek, Komendantova, \& Patt, 2015; Schmidt, 2014) or restrict high-carbon investment (Caldecott, 2019; Erickson, Down, Lazarus, \& Koplow, 2017; Fattouh, Rahmatallah, \& West, 2019).

However, primary and secondary markets do not operate in isolation. Ex-ante expectations of secondary market liquidity (a function of investor demand, as well as other factors) reduces the cost of capital in primary markets (Goldstein, Hotchkiss, \& Pedersen, 2019). Furthermore, secondary markets are used as a benchmark for price formation in 
primary markets, with new issues often priced at a discount to seasoned offerings (Fridson \& Gao, 1996; Mola \& Loughran, 2004). Therefore, changes in secondary market prices, whether through capital allocation or changes in investor preferences and expectations, can deliver real economy impact, but once primary markets are accessed, with a change in the cost of capital most material for companies in need of external finance (Baker, Stein, \& Wurgler, 2003). Primary markets can therefore be thought of as the point of maximum leverage for delivering ACO.

Historically, Scholtens (2006) outlines how sustainable finance has overlooked primary markets, instead focusing on shareholders as a mechanism for impact. Indeed, Urban and Wójcik (2019) note that instead of going to the root of the issue, sustainable finance has conducted a "taxonomic exercise that aims at labelling old finance" with respect to environmental factors. To make finance truly sustainable, these factors must be embedded in primary markets.

\subsection{Portfolio Climate Alignment}

If the profile of primary market transactions reflects the underlying portfolio, then reductions in carbon exposure, for example through divestment (Hunt \& Weber, 2019), will reduce the carbon exposure of portfolio flows going forward. This is underscored by Cojoianu, Ascui, Clark, Hoepner, and Wójcik (2020), who show that divestment commitments reduce carbonintensive capital flows. Furthermore, a "Divestlnvest" strategy can be deployed, whereby capital freed up through divestment is channelled into low-carbon assets (Divestlnvest, 2018).

However, certain investors may be unable to immediately alter portfolio holdings. For example, a passive fund with a mandate to minimise tracking error relative to an index, or a buy and hold strategy. Yet, in these instances, improvements in the alignment of portfolio flows can still be achieved by strategically selecting which primary market transactions to partake in. Although this strategy may lead to cause investors to lose out on new issue premiums in carbon-intensive sectors, De Jong and Nguyen (2016) show that a 50\% reduction in the carbon-intensity of a global corporate bond portfolio can be achieved without affecting tracking error.

In summary, full divestment from carbon-intensive sectors is not a prerequisite for improvements in the climate alignment of primary markets transactions. Even passive funds can alter their capital allocation in primary markets. As previously detailed, changes in demand in primary markets can alter the cost of capital faced by companies, a key mechanism for 
causing impact in the real economy. This underscores the need to track primary market transactions, both from the perspective of investors and policymakers, as it is capital raised through primary markets that will finance the low-carbon transition.

\section{Methodology}

\subsection{Primary Market Carbon Exposure}

To track portfolio flows, we use a metric called Primary Market Carbon Exposure (PMCE). This metric is a time-bound measure of portfolio flows to the real economy, calculated as the proportion of total primary market transactions for a given financial institution or portfolio that occur in carbon-intensive sectors. Carbon-intensive sectors are defined as those that operate in fossil fuel industries, covering coal mining, oil \& gas, and non-renewable electric and gas utilities (TCFD, 2017).

$$
P M C E_{\text {Period } T}=\frac{\text { Carbon Intensive Capital Flows } \text { Period T }}{\text { Total Capital Flows Period T }}
$$

As previously highlighted, bonds account for a significant share of carbon-intensive financing relative to equity. For investors targeting net zero portfolios in line with the Paris agreement, PMCE should reach zero before 2050, as capital supplied to carbon-intensive companies can be used to finance new projects with long lifespans that result in carbon lockin (Unruh, 2000). In this context, portfolio flows can act as a leading indicator, mirroring company-level transitions in the real economy. For example, for an energy company to transition, the proportion of CAPEX that is low-carbon needs to be higher than the existing stock of low-carbon assets relative to total assets. Similarly, for a portfolio to transition, PMCE will need to be lower than a portfolio's current exposure to carbon-intensive assets. We recognise that the reality is more complex, as financing for carbon-intensive companies can support their transition. Therefore, in practice, when selecting primary market investments, investors may need to use forward looking metrics to identify which companies are set to successfully transition and not contribute to carbon lock-in.

To demonstrate PMCE in practice we use fixed-income ETFs. This could be replicated in other asset classes, however we focus on fixed-income ETFs for the following reasons. First, bonds account for a significant share of overall carbon-intensive financing, as shown in Figure 2. Second, unlike mutual funds, ETFs disclose daily holdings allowing for trades to be tracked. Third, in fixed income, passive investing accounted for $30 \%$ of fund AUM in 2020, up from less 
than 5\% in 1995 (Anadu et al., 2020). ETFs account for approximately half of passive fund AUM, as well as half of passive fixed-income fund inflows over the past decade (Anadu et al., 2020). Using these ETFs provides an insight into a rapidly growing part of fixed income and its ability to shape primary markets.

\subsection{Selecting ETFs}

To obtain ETFs holdings, data was obtained from Bloomberg in 40-day windows and then combined into matrixes for 1st January 2015 to 31st December 2020. Due to the limitations of this manual approach, only the largest ETFs were selected, defined as those with over $\$ 500$ million of AUM in US-issued corporate bonds as of 1st November 2020. ETFs selected must provide broad-based exposure to US investment grade (IG) or high yield (HY) bonds within their corporate bond allocations (excluding ETFs that invest in a single rating, sector, or maturity) and disclose daily holdings. Based on these criteria, 35 ETFs were selected, split into 23 IG and 12 HY ETFs. As of 1st November 2020, the IG ETFs held \$114 billion of US corporate bonds and the HY ETFs held $\$ 66$ billion. Combined, these ETFs account for $3 \%$ of fixed-income ETFs in number but $44 \%$ of ETF US corporate bond holdings in terms of AUM (Table 2). Certain ETFs hold a combination of government bonds, mortgage-backed securities, municipal bonds, and corporate bonds, however PMCE is only calculated for corporate bond holdings. Certain ETFs in the sample also include debt issued in currencies other than USD. In these instances, values are converted into USD. Vanguard ETFs are not in scope, as daily holdings data are not available on Bloomberg. The selected ETFs are listed in Appendix A.

\begin{tabular}{|l|r|r|r|}
\hline & All ETFs & ETFs in Scope & Coverage \\
\hline Number of funds & 1613 & 35 & $3 \%$ \\
\hline All AUM (\$bn) & 1413 & 307 & $22 \%$ \\
\hline Corporate Bond AUM (\$bn) & 643 & 244 & $38 \%$ \\
\hline US Corporate Bond AUM (\$bn) & 475 & 210 & $44 \%$ \\
\hline
\end{tabular}

Table 2. Scope of ETFs selected.

Source. Data from Bloomberg, November 2020.

Using daily holdings data, an ETF trade is identified when a new bond identifier (ISIN) appears in the portfolio. The trade date is compared to the bond's pricing date in Eikon, with 
business days between the Days After Issuance (DAI). If DAl is 0 , the trade is tagged as a primary market trade. To demonstrate this, using CUSIPs we match 4,821 bonds traded by the ETFs with TRACE transaction data. TRACE Enhanced shows that although secondary market trades occur on DAI 0, primary market trades account for $91 \%$ of trade volume and $97 \%$ of trade value (Figure 3 ).

However, within 10 days of issuance, on average $34 \%$ of ETF trades occur at DAI 0 and $42 \%$ at DAI 1 (Figure 3). This split is significantly different to TRACE, yet the combined proportion of DAI 0 and DAI 1 trades is similar at $80 \%$ for TRACE and $76 \%$ for ETFs. This is likely to be caused by a reporting delay. The SEC requires ETFs to disclose portfolio holdings on a daily basis (SEC, 2014) with ETFs submitting a portfolio composition file (PCF) at the end of each trading day to the National Securities Clearing Corporation (NSCC) (ICI, 2014). Holdings reported relate to Net Asset Value calculations that occur at 16:00 Eastern time when the New York Stock Exchange closes (ICl, 2014). In our sample, $27 \%$ of primary market trades in TRACE occur after the market close and therefore would not be included. Furthermore, new issues are reported differently depending on the ETF provider. The proportion of trades at DAI $0-1$ is similar across ETF providers but the distribution varies (Figure 3).

Therefore, DAI 1 trades are counted as primary market trades for this analysis. This assumption was checked with market practitioners that trade ETFs. By using both DAI 0 and DAI 1 trades as primary market trades, TRACE data indicates that primary market trade values will be overestimated by approximately $7 \%$, as secondary market trades occur on both DAI 0 and 1 (Figure 3). However, as the focus of our analysis is the proportion of primary market trades that occur in carbon-intensive relative to other sectors, primary market trade values are not adjusted. 


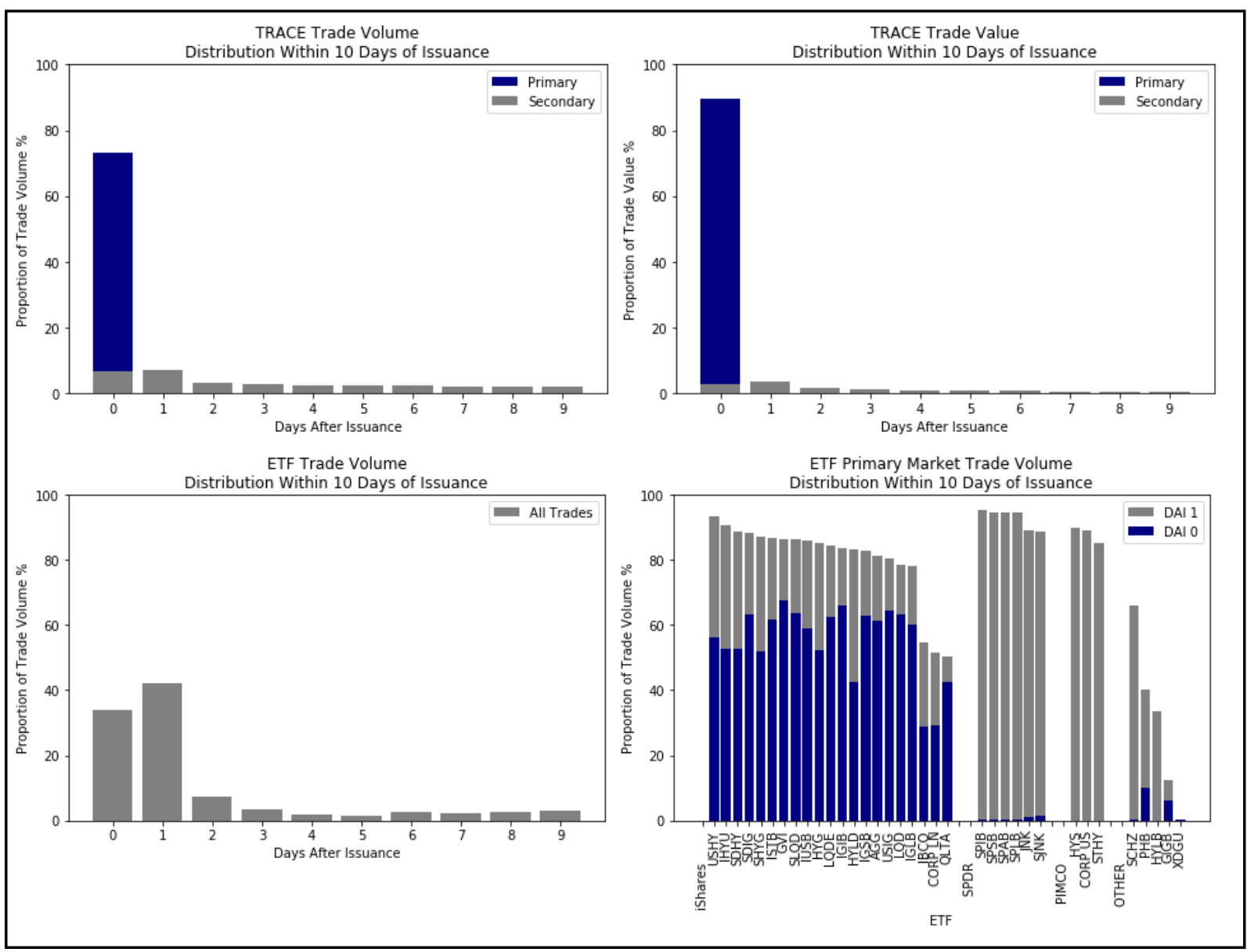

Figure 3. TRACE and ETF Trade Distribution

Source: Data from Bloomberg and TRACE.

Note. In TRACE Enhanced, transactions are tagged as primary market (P1) or secondary market (S1) and whether they occur between dealers (FINRA members) or with non-FINRA members, such as institutional investors. Only sell trades to investors are used.

\section{Results}

Using this approach, 38,757 primary market trades are extracted across 9,956 bonds. These are used to calculate PMCE on an aggregate basis and for each ETF. Figure 4 shows a combined PMCE of $13.6 \%$ for the ETFs over 2015-2020. At the ETF level, PMCE ranged from $6.8 \%$ to $29.1 \%$, with an average of $14.5 \%$. Here, only ETFs with over 100 primary market trades are considered (29 out of 35), as ETFs with very few primary markets trades can have an artificially inflated PMCE.

These findings show that ETFs actively partake in primary market transactions despite tracking indexes that rebalance monthly. This trading is likely to occur to capture new issue premiums in primary markets, with issues under-priced to attract investors (Fridson \& Gao, 
1996). Whether an ETFs focuses on IG or HY bonds is a key factor in determining PMCE. The average PMCE for HY ETFs is $19.8 \%$ but $12.4 \%$ for IG ETFs. Another key determinant is the underlying carbon exposure of an ETFs corporate bond holdings, with PMCE reflecting the carbon exposure of the underlying portfolio (Figure 4). For asset owners concerned about financing carbon lock-in, this demonstrates the need to consider the interplay between portfolio holdings and portfolio flows.

PMCE scores can be broken down into different carbon-intensive sectors, as shown by Table 3, using TRBC activity classifications (Appendix B). In addition to the ETFs, we calculate PMCE for the entire market, looking at all corporate bonds issued. Relative to global corporate bond issuance, a negligible proportion of ETF financing occurs in coal mining, at $0.04 \%$ versus $1.1 \%$. For the ETFs in the sample, upstream oil \& gas accounts for $3.80 \%$ of financing, mid and downstream oil \& gas accounts for $5.32 \%$, and electric and gas utilities account for $4.4 \%$. As well as differences in sector allocation, Table 3 shows that PMCE for ETFs in the sample $(13.6 \%)$ is higher than the global corporate bond market $(10 \%)$. However, over $2015-2020$ the US accounted for $30.8 \%$ of global corporate bond issuance, while in the ETF sample, US issuance was $80.3 \%$ of the total. To account for this difference, Table 3 shows PMCE for USD issuance by US issuers only, resulting in a PMCE of $14.7 \%$ for the ETFs and $11.5 \%$ for all US corporate bond issuance.

To investigate why ETFs still have a higher PMCE than the broader market, Table 3 splits transactions into IG and HY. The sector split for US bond issuance shows that in HY, the proportion of upstream oil \& gas financing is higher than IG, at $9.7 \%$ and $0.9 \%$ respectively. For electric and gas utilities, the $\mathrm{HY}$ allocation is lower relative to $\mathrm{IG}$, at $3.3 \%$ and $6.6 \%$ respectively. For asset owners investing in ETFs, climate risk and the potential for carbon lock therefore differs depending on the type of corporate bond exposure. For IG, financing is focused on utilities and mid to downstream oil \& gas, while for HY, financing is focused on upstream oil \& gas exploration and production. Table 3 also shows a clear difference between IG and HY for overall PMCE. This is the case for the US corporate bond market and for the ETFs in the sample. For US bond issuance, PMCE is $10.7 \%$ for IG and $15.8 \%$ for HY. We observe that in the US market, HY issuance accounted for $16.2 \%$ of transaction value over 2015-2020, while for the ETFs in our sample, HY issuance accounted for $33.8 \%$ of the transaction value. This relative overweight to $\mathrm{HY}$ in the sample will drive a higher PMCE relative to the market. 

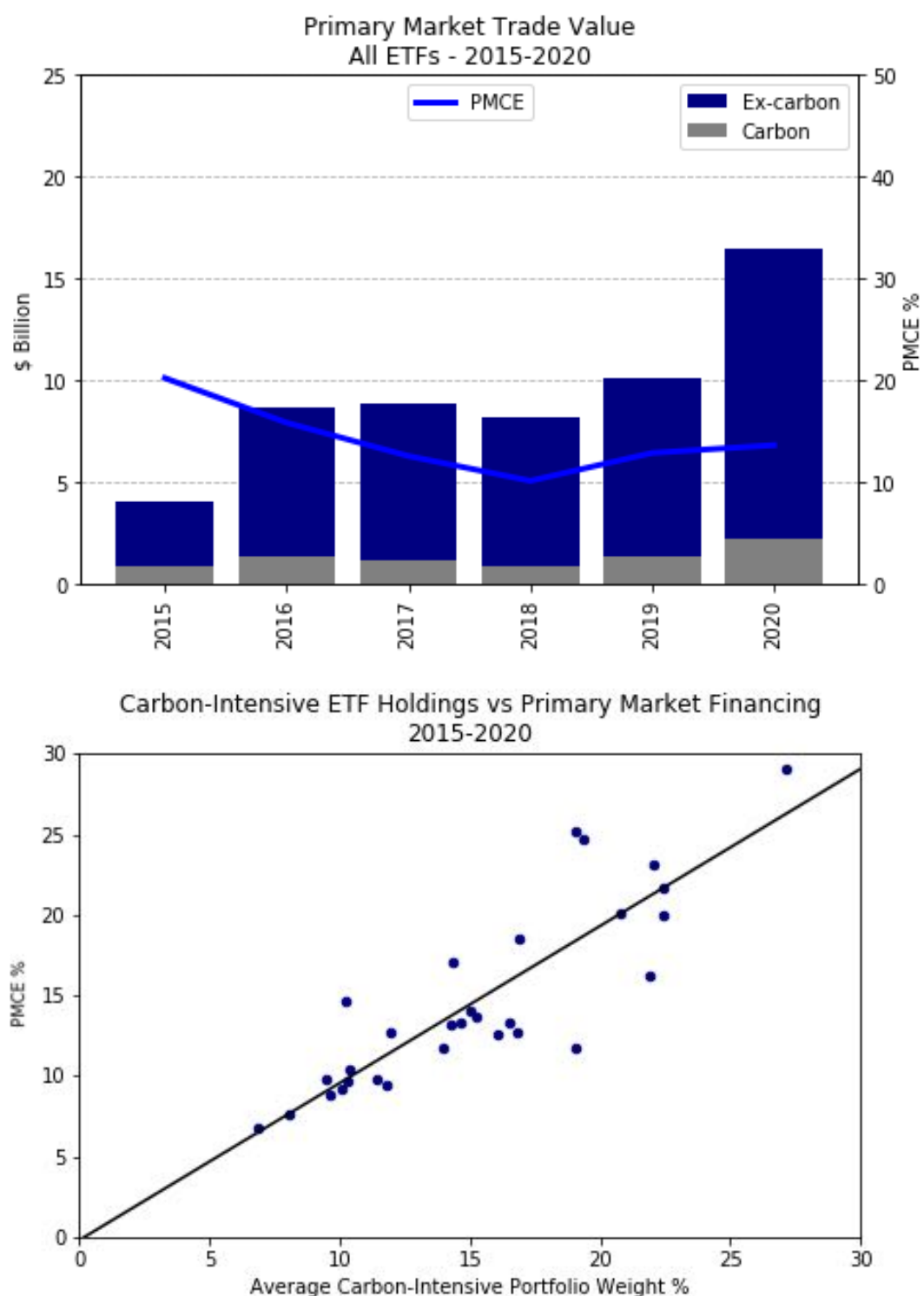

Figure 4. Aggregate and Individual ETF PMCE

Source. Data from Eikon and Bloomberg.

Note. When plotting the yearly average portfolio weight in carbon-intensive assets against PMCE, only ETFs with over 100 identified primary market trades are shown. 


\begin{tabular}{|l|cccccc|}
\hline & $\begin{array}{c}\text { Time } \\
\text { Period }\end{array}$ & $\begin{array}{c}\text { Electric } \\
\text { and Gas } \\
\text { Utilities }\end{array}$ & $\begin{array}{c}\text { O\&G } \\
\text { Upstream }\end{array}$ & $\begin{array}{c}\text { O\&G Mid- } \\
\text { Downstream }\end{array}$ & $\begin{array}{c}\text { Coal } \\
\text { Mining }\end{array}$ & Total \\
\hline Global Corp Bond Issuance & $2015-2020$ & $4.77 \%$ & $1.84 \%$ & $2.30 \%$ & $1.06 \%$ & $9.97 \%$ \\
US Corp Bond Issuance & $2015-2020$ & $4.91 \%$ & $1.96 \%$ & $4.59 \%$ & $0.08 \%$ & $11.54 \%$ \\
IG US Corp Bond Issuance & $2015-2020$ & $5.47 \%$ & $0.99 \%$ & $4.24 \%$ & $0.00 \%$ & $10.70 \%$ \\
HY US Corp Bond Issuance & $2015-2020$ & $2.07 \%$ & $6.94 \%$ & $6.38 \%$ & $0.44 \%$ & $15.83 \%$ \\
\hline Global Corp Bond ETF Trades & $2015-2020$ & $4.44 \%$ & $3.80 \%$ & $5.32 \%$ & $0.04 \%$ & $13.60 \%$ \\
US Corp Bond ETF Trades & $2015-2020$ & $5.38 \%$ & $4.28 \%$ & $5.00 \%$ & $0.03 \%$ & $14.68 \%$ \\
IG US Corp Bond ETF Trades & $2015-2020$ & $6.63 \%$ & $0.88 \%$ & $3.92 \%$ & $0.00 \%$ & $11.43 \%$ \\
HY US Corp Bond ETF Trades & $2015-2020$ & $3.26 \%$ & $9.86 \%$ & $7.32 \%$ & $0.08 \%$ & $20.53 \%$ \\
\hline Federal Reserve ETFs & $2015-2020$ & $3.68 \%$ & $4.06 \%$ & $5.31 \%$ & $0.04 \%$ & $13.10 \%$ \\
Federal Reserve ETFs & 2020 & $3.70 \%$ & $4.14 \%$ & $5.18 \%$ & $0.00 \%$ & $13.01 \%$ \\
\hline
\end{tabular}

Table 3. PMCE by Sector

Source. Data from Eikon and Bloomberg.

Note. 13 out of 16 ETFs bought by the Federal Reserve in 2020 are captured.

However, Table 3 shows that within IG and HY there is still variation between the ETFs and the broader US market. This is shown in Figure 5, where although the US market and US ETFs have similar PMCE scores for IG, at $10.7 \%$ and $11.4 \%$, for $\mathrm{HY}$ the variation is larger, at $15.8 \%$ and $20.5 \%$. To explore why ETF financing is more carbon-intensive in HY than the market, Figure 5 shows the share of primary market issuance accounted for by the ETFs, comparing carbon-intensive and non-carbon-intensive sectors. In this context, the share of primary market issuance is the combined proportion of a new issue bought by the ETFs. For IG ETFs, the difference between carbon and non-carbon-intensive sectors is negligible at $0.04 \%$, and not statistically significant. For HY ETFs, the difference is $+0.41 \%$ and statistically significant at the $1 \%$ level (see Appendix C). This shows that HY ETFs account for a larger share of carbon-intensive demand in primary markets, increasing PMCE relative to the broader market. As shown in Appendix D, ETF demand within our sample is highest in energy and utilities sectors. Smaller issue sizes in carbon-intensive sectors may play a role. However, as shown in Appendix $\mathrm{C}$, the difference between carbon-intensive and non-carbon-intensive issue size is smaller in HY than IG.

In recent years, certain asset managers and owners have reduced the carbon exposure of their portfolios (Boermans \& Galema, 2019; Mésonnier \& Nguyen, 2021), while 
investors with approximately $\$ 14.5$ trillion in assets have divested from fossil fuels (Fossil Free, 2021) reducing capital flows to carbon-intensive sectors (Cojoianu et al., 2020). As active investors avoid riskier carbon-intensive assets, passive ETFs could be stepping in.

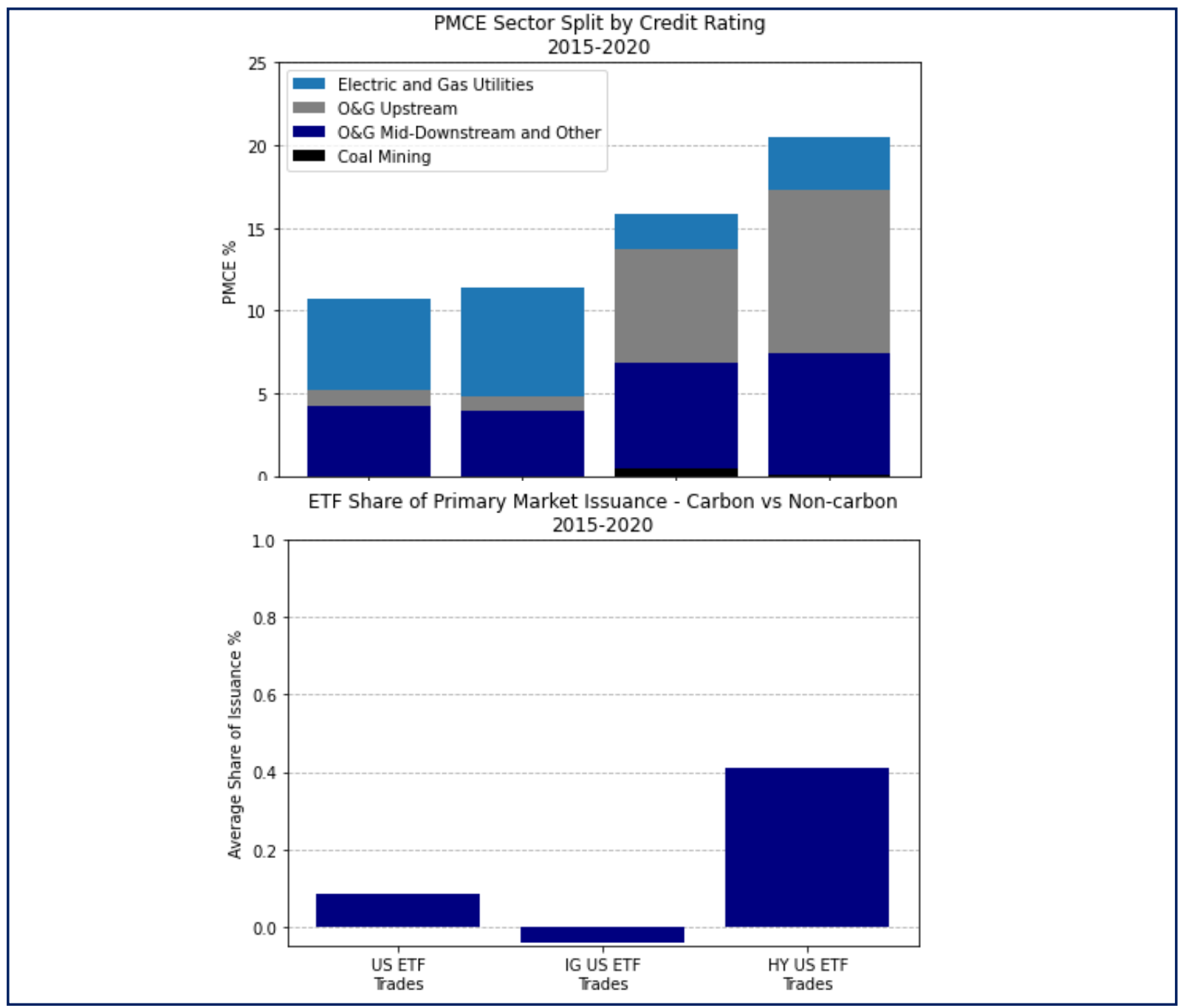

Figure 5. PMCE and Primary Market Demand by Rating.

Source. Data from Eikon and Bloomberg.

\section{Discussion: Implications and Further Research}

These findings show that ETFs systematically take active decisions to partake in new bond issues before inclusion in indexes at the monthly rebalancing date (Appendix E). From the perspective of an asset owner, this demonstrates the importance of selecting a passive fund that tracks a low-carbon index. However, there are also implications for ETF providers that continue to offer carbon-intensive ETFs. 
If these passive funds that track carbon-intensive indexes do not partake in primary market transactions in carbon-intensive sectors, there is the potential that performance would be negatively affected, as new issue premiums would not be captured. However, any performance lost in the short-term needs to be weighed against the long-term economy-wide benefits of avoiding carbon lock-in. Quigley (2019) therefore makes the case that investors should act as a universal owner and apply a decarbonisation mandate to primary market transactions. More broadly, the large share of financing for carbon-intensive sectors from corporate bonds underscores the need for bondholders to actively engage with investee companies and ensure that companies financed are transitioning in line with the Paris Agreement (Hoepner \& Schneider, 2020).

Relative to an active investor that can fully divest, passive funds are often required to hold carbon-intensive assets, as they aim to reduce tracking error relative to an index (Aber \& $\mathrm{Li}, 2009)$. However, there is scope to be selective with regard to the companies financed through primary markets. For example, only financing carbon-intensive companies with robust transition plans. In fact, the largest ETF providers advertise their ability to deploy credit research to identify the best opportunities in primary markets (Vanguard, 2020) - this active security selection could be extended to consider climate factors. Furthermore, as indexes tracked can include up to 10,000 securities, ETFs deploy stratified sampling techniques to replicate index returns (BlackRock, 2021; State Street Global Advisors, 2021). Therefore, in addition to integrating climate factors into primary market investment decisions, there is scope to reflect these factors in ETF holdings alongside the objectives of minimising tracking error and ensuring liquidity. For example, De Jong and Nguyen (2016) show that the carbonexposure of a corporate bond portfolio can be reduced by over $50 \%$ without impacting tracking error. These steps could help prevent passive funds from becoming both "holders of last resort" (Jahnke, 2019) and financiers of last resort for carbon-intensive companies, as other investors step back from carbon-intensive sectors (Mésonnier \& Nguyen, 2021).

These findings also have implications for policymakers, such as central banks. In our sample, fixed income ETF AUM grew 200\% since 2015 (Figure 6). This rapid expansion is underscored by the jump in primary market financing seen in 2020, with Figure 4 showing a year-on-year increase of $62 \%$ overall and a $72 \%$ increase for carbon-intensive sectors. This was driven by two factors. First, the Covid-19 induced economic crisis resulted in significant corporate debt issuance (Halling, Yu, \& Zechner, 2020), with 2020 issuance reaching record levels and marking a 50\% year-on-year increase (SIFMA, 2021). Second, the AUM of ETFs 


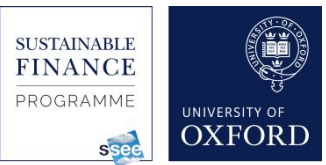

in the sample increased by $36 \%$ in 2020 , equivalent to $\$ 87$ billion of inflows. These inflows were prompted by the Federal Reserve's decision to buy corporate bond ETFs for the first time. Although the Bank of Japan has been buying equity ETFs since 2011 as part of its quantitative easing programme (Charoenwong, Morck, \& Wiwattanakantang, 2020), the Fed is the first to purchase corporate bond ETFs. In March 2020, the Fed announced an initial allocation of $\$ 25$ billion in its Secondary Market Corporate Credit Facility (SMCFF) for corporate bonds and US-listed ETFs that provide a broad US corporate bond exposure (Federal Reserve, 2020). At the end of 2020, the Fed had purchased $\$ 8.8$ billion across 16 ETFs (Federal Reserve, 2021). Although small relative to overall inflows, the announcement improved trading conditions and market confidence (Boyarchenko, Kovner, \& Shachar, 2020; Kargar et al., 2020; O'Hara \& Zhou, 2020), decreasing the perception of credit risk and supporting issuance (D’Amico, Kurakula, \& Lee, 2020).

Out of the 16 ETFs bought by the Fed, 13 are in scope of this paperiii (Figure 6). Although not held by the Fed over 2015-2020, the combined PMCE for this period was $13.1 \%$. In 2020 , PMCE was $13 \%$, with no financing of coal mining, $4.1 \%$ in upstream oil \& gas, $5.2 \%$ in mid to downstream oil \& gas, and $3.7 \%$ in electric and gas utilities (Table 3 ). The Fed has a separate facility for primary markets - the Primary Market Corporate Credit Facility (PMCCF). However, we show that ETFs also partake in primary markets. Therefore, in the context of the low-carbon transition, central banks need to factor in the climate impact of ETFs purchased, in addition to direct corporate bond purchases.

More broadly, the growth of ETFs and passive investing should be a focus of policymakers working at the intersection of climate change and financial markets. To date, policies dealing with climate risks have focused on the provision of climate-related disclosures by companies to market participants (European Commission, 2020; HM Treasury, 2020; TCFD, 2017). Such disclosures are expected to address under-pricing of these risks (Thomä \& Chenet, 2017), allowing markets to price them correctly and allocate capital accordingly (Christophers, 2017; Cullen, 2018). However, given the growing market share of passive funds, the efficacy of these policies could be limited, with passive investors buying securities based on index eligibility rather than risk characteristics. This "free-riding" on active investors could reduce the information embedded in prices (Turner, 2018). Furthermore, for USdomiciled passive funds, just $0.6 \%$ of $A U M$ is invested in sustainable strategies, while in Europe, this figure is $9.2 \%$ (Morningstar, 2020). For those passive funds invested in sustainable strategies, only $9 \%$ of assets are in fixed income (Morningstar, 2020). As passive 
demand can reduce the cost of capital and increase corporate debt issuance (Bessembinder et al., 2020; Dathan \& Davydenko, 2018; Ottonello, 2018), further research is required to examine how passive investing affects the pricing of climate risk.

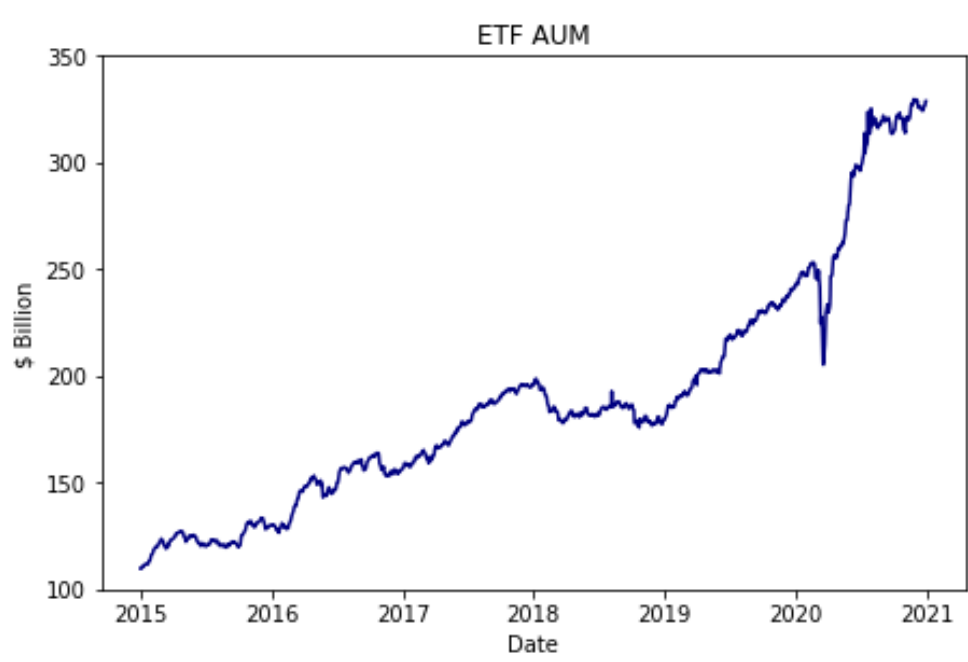

Federal Reserve - Secondary Market Corporate Credit Facility ETFs Purchased - PMCE - 2015-2020

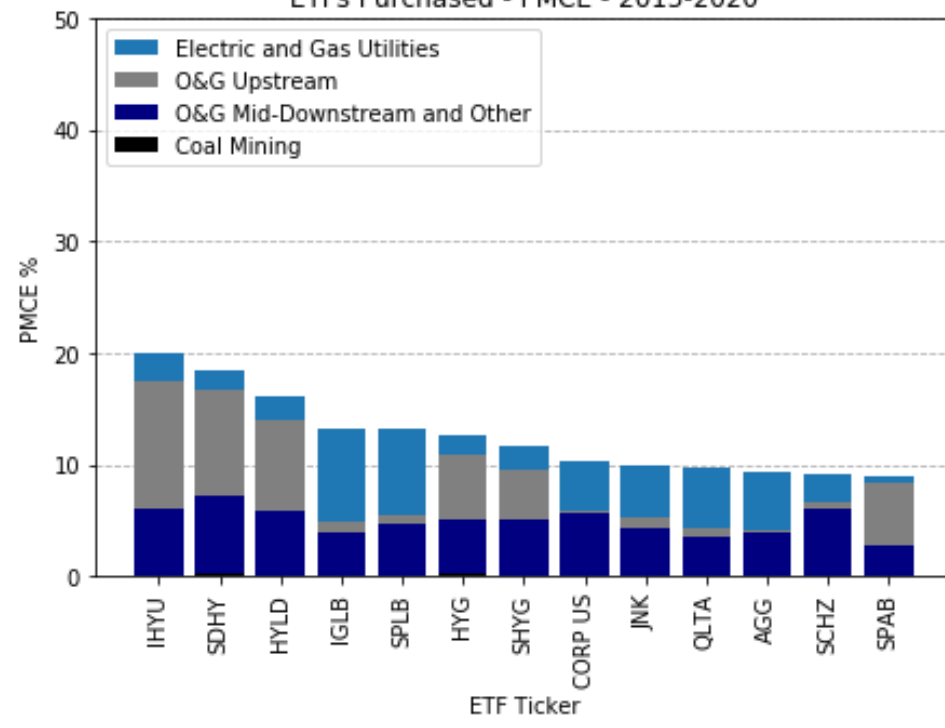

Figure 6. ETFs and the Federal Reserve.

Source. Data from Eikon, Bloomberg, and the Federal Reserve.

Note. In 2020 the Federal Reserve bought 16 corporate bond ETFs. Here 13 are shown, as two Vanguard ETFs do not provide daily holdings data and the VanEck Fallen Angels ETF did not meet the criteria for this analysis.

Chenet et al. (2020) argue that due to the potential severity of climate risk, and the radical uncertainty that prevents the accurate estimation of this risk, rather than focus on market-based solutions alone a precautionary market-shaping approach (Mazzucato, 2016) is needed to actively guide markets towards an optimal scenario where climate risks are 
mitigated. In line with this approach, the current structure of passive investing warrants attention by policymakers, with dominant passive products hardwired to finance carbonintensive assets irrespective of climate risk.

In this context, actions to be considered by policymakers include supporting the development of low-carbon indices, for example through the EU Low Carbon Benchmark Regulation. Similarly, asset owners can be encouraged to set low-carbon funds and benchmarks as the default choice for savers. Policies such as Article 173 in France that requires institutional investors to report on climate-related exposures (Mésonnier \& Nguyen, 2021) and the EU Sustainable Finance Disclosure Regulation (SFDR) that requires environmental financial products to disclosure the proportion of investments that are sustainable (European Commision, 2020), could be extended to require investors to report on their financing activities through primary markets, for example through metrics such as PMCE. This transparency could promote the integration of climate factors into primary market investment decisions, in turn incentivising companies to remain eligible for financing from investors with Paris alignment commitments. Applied to passive funds, this could enable the differentiation between similar index tracking funds.

\section{Conclusion}

This paper has outlined why a focus on portfolio flows is necessary to align the financial system with the Paris Agreement. Although measures of climate alignment based on portfolio holdings provide insights into climate risk, this is not the same as tracking Alignment with Climate Outcomes, as improvements secured through secondary markets bypass the real economy. Therefore, investors need to track portfolio flows, with primary markets able to finance new infrastructure and alter the cost of capital obtained by companies.

Portfolio flows must be decarbonised well before 2050 to avoid carbon lock-in and reduce systemic climate risk (Quigley et al., 2020). A system-wide focus on primary markets by investors could act as a Sensitive Invention Point in the net zero carbon transition (Farmer et al., 2019). For example, the introduction of primary market metrics into reporting frameworks could accelerate the pricing of climate externalities in primary markets and amplify pressure on companies to remain eligible for Paris-aligned finance.

In this context, we have shown that US corporate bond ETFs allocated $13.6 \%$ of their primary market portfolio flows to carbon-intensive sectors from 2015 to 2020 , with $0.04 \%$ in coal mining, $3.8 \%$ in upstream oil \& gas, $5.3 \%$ in mid and downstream oil \& gas, and $4.4 \%$ in 
electric and gas utilities. Furthermore, ETFs bought by the Federal Reserve in 2020 allocated $13 \%$ of primary market investments to carbon-intensive sectors. Given the growing power of passive investing, this presents two issues for policymakers. First, will the efficacy of climaterelated disclosures be limited? And second, will the financing activities of passive funds result in carbon-lock?

As primary markets can be considered the point of maximum leverage, ETF providers serious about climate change must consider how they can align portfolio flows. For ETFs that track carbon-intensive indexes, this is crucial. Although these funds may hold carbon-intensive assets to reduce tracking error relative to an index, this does not prevent a reduction in carbonintensive financing through primary markets. 
Appendix A - ETFs in Scope

\begin{tabular}{|c|c|c|c|c|}
\hline Ticker & Name & $\begin{array}{l}\text { AUM } \\
(\$ \mathrm{~m})\end{array}$ & $\begin{array}{l}\text { US CORP } \\
\text { AUM (\$m) }\end{array}$ & $\begin{array}{l}\text { PMCE } \\
2015-2020\end{array}$ \\
\hline LQD & iShares iBoxx \$ IG Corp Bond ETF & 56297 & 48536 & $9.2 \%$ \\
\hline HYG & iShares iBoxx \$ HY Corp Bond Fund & 27959 & 24852 & $20.0 \%$ \\
\hline AGG & iShares Core US Aggregate Bond ETF & 80735 & 23025 & $14.1 \%$ \\
\hline IGSB & iShares 1-5 Year IG Corp ETF & 20333 & 15310 & $9.4 \%$ \\
\hline JNK & SPDR Bloomberg Barclays HY Bond ETF & 12998 & 11204 & $16.2 \%$ \\
\hline LQDE & iShares \$ Corp Bond UCITS ETF & 7961 & 9443 & $9.7 \%$ \\
\hline IGIB & iShares 5-10 Year IG Corp Bond ETF & 11677 & 9331 & $13.3 \%$ \\
\hline IHYU & iShares \$ HY Corp Bond ETF & 4979 & 6570 & $29.1 \%$ \\
\hline HYLB & Xtrackers \$ HY Corp Bond ETF & 6774 & 5977 & - \\
\hline SPSB & SPDR Portfolio Short Term Corp Bond ETF & 6815 & 5642 & $10.4 \%$ \\
\hline USHY & iShares Broad \$ High Yield Corp Bond ETF & 6233 & 5519 & $11.7 \%$ \\
\hline SPIB & SPDR Portfolio Intermediate Term Corp Bond ETF & 6154 & 5352 & $9.9 \%$ \\
\hline USIG & iShares Broad \$ IG Corp Bond & 5753 & 4744 & $13.2 \%$ \\
\hline SHYG & iShares 0-5 Year High Yield Corporate Bond ETF & 5025 & 4454 & $18.5 \%$ \\
\hline SDIG & iShares \$ Short Duration Corp Bond ETF & 2096 & 4368 & $8.8 \%$ \\
\hline SJNK & SPDR Bloomberg Barclays Short Term HY Bond ETF & 3579 & 3117 & $12.7 \%$ \\
\hline $\mathrm{SCHZ}$ & Schwab US Aggregate Bond ETF & 8300 & 2165 & $13.7 \%$ \\
\hline CORP LN & iShares Global Corp Bond ETF & 1389 & 1930 & $7.7 \%$ \\
\hline SLQD & iShares 0-5 Year IG Corp ETF & 2018 & 1658 & $9.8 \%$ \\
\hline IGLB & iShares 10+ Year IG Corp Bond ETF & 1814 & 1599 & $23.2 \%$ \\
\hline IUSB & iShares Core Total \$ Bond Market ETF & 5452 & 1571 & $12.7 \%$ \\
\hline ISTB & iShares Core 1-5 Year USD Bond ETF & 4622 & 1499 & $12.7 \%$ \\
\hline XDGU & Xtrackers \$ Corp Bond ETF & 1048 & 1457 & - \\
\hline SPAB & SPDR Portfolio Aggregate Bond ETF & 5512 & 1378 & $13.3 \%$ \\
\hline QLTA & iShares Aaa - A Rated Corp Bond ETF & 1474 & 1296 & $14.7 \%$ \\
\hline IBCQ & iShares Global Corp Bond EUR Hedged ETF & 1808 & 1116 & $6.8 \%$ \\
\hline HYLD & iShares Global HY Corp Bond ETF & 743 & 1055 & $24.8 \%$ \\
\hline STHY & PIMCO US Short Term HY Corp Bond ETF & 372 & 937 & - \\
\hline SDHY & iShares \$ Short Duration HY Corp Bond ETF & 720 & 880 & $25.2 \%$ \\
\hline SPLB & SPDR Portfolio Long Term Corp Bond ETF & 881 & 824 & $20.0 \%$ \\
\hline PHB & Invesco Fundamental HY Corp Bond ETF & 783 & 771 & - \\
\hline HYS & PIMCO 0-5 Year High Yield Corp Bond ETF & 1174 & 770 & - \\
\hline GVI & iShares Intermediate Government/Credit Bond ETF & 2283 & 740 & $11.7 \%$ \\
\hline CORP US & PIMCO IG Corp Bond Index ETF & 808 & 576 & $17.0 \%$ \\
\hline GIGB & Goldman Sachs Access IG Corp Bond ETF & 651 & 568 & - \\
\hline
\end{tabular}

Source. Data from Bloomberg.

Note. PMCE is only shown for ETFs with over 100 primary market trades identified. 
Appendix B - TRBC Activity Classifications

\begin{tabular}{|l|l|}
\hline $\begin{array}{l}\text { Electric and } \\
\text { Gas Utilities }\end{array}$ & $\begin{array}{l}\text { Electric Utilities (NEC), Electric Power Plant Construction, Fossil Fuel Electric Utilities, } \\
\text { Independent Power Producers (NEC), Fossil fuel IPPs, Natural Gas Utilities (NEC), Natural } \\
\text { Gas Distribution }\end{array}$ \\
\hline $\begin{array}{l}\text { O\&G } \\
\text { Upstream }\end{array}$ & $\begin{array}{l}\text { Oil Related Services and Equipment (NEC), Oil Related Services, Oil \& Gas Transportation } \\
\text { Services (NEC), Oil \& Gas Refining and Marketing (NEC), Natural Gas Pipeline } \\
\text { Transportation, LNG Transportation \& Storage, Oil Pipeline Transportation, Petroleum } \\
\text { Refining, Petroleum Product Wholesale, Integrated Oil \& Gas }\end{array}$ \\
\hline $\begin{array}{l}\text { O\&G Mid- } \\
\text { Downstream }\end{array}$ & $\begin{array}{l}\text { Oil \& Gas Exploration and Production (NEC), Oil Exploration \& Production - Onshore, Oil \& } \\
\text { Gas Drilling (NEC), Oil Drilling - Offshore, Unconventional Oil \& Gas Production, Natural } \\
\text { Gas Exploration \& Production - Onshore }\end{array}$ \\
\hline Coal Mining & Coal (NEC), Coke Coal Mining, Coal Mining Support \\
\hline
\end{tabular}

Appendix C - ETF Share of Demand by Rating

\begin{tabular}{|c|c|c|c|c|c|c|c|}
\hline \multicolumn{2}{|l|}{ 2015-2020 } & \multicolumn{6}{|c|}{ Aggregate ETF Trades } \\
\hline & & All & IG & HY & US & US IG & US HY \\
\hline \multirow{2}{*}{$\begin{array}{l}\text { No. Bond } \\
\text { Issues }\end{array}$} & Carbon-Intensive & 1440 & 1112 & 315 & 1148 & 876 & 268 \\
\hline & Ex-Carbon-Intensive & 8545 & 6480 & 1955 & 5752 & 4417 & 1260 \\
\hline \multirow{4}{*}{$\begin{array}{l}\text { ETF Share of } \\
\text { New Issue } \\
\text { Demand }\end{array}$} & Carbon-Intensive & $0.76 \%$ & $0.53 \%$ & $1.49 \%$ & $0.85 \%$ & $0.59 \%$ & $1.63 \%$ \\
\hline & Ex-Carbon-Intensive & $0.64 \%$ & $0.53 \%$ & $0.99 \%$ & $0.76 \%$ & $0.63 \%$ & $1.22 \%$ \\
\hline & Difference & $0.12 \%$ & $-0.00 \%$ & $0.50 \%$ & $0.08 \%$ & $-0.04 \%$ & $0.41 \%$ \\
\hline & Difference P-Value & 0.00 & 0.85 & 0.00 & 0.00 & 0.12 & 0.00 \\
\hline \multirow{4}{*}{$\begin{array}{c}\text { Issue Size (\$ } \\
\text { Million) }\end{array}$} & Carbon-Intensive & 779 & 790 & 742 & 739 & 731 & 754 \\
\hline & Ex-Carbon-Intensive & 1017 & 1074 & 824 & 1027 & 1087 & 825 \\
\hline & Difference & -238 & -284 & -82 & -288 & -356 & -71 \\
\hline & Difference P-Value & 0.00 & 0.00 & 0.00 & 0.00 & 0.00 & 0.00 \\
\hline
\end{tabular}

Source. Data from Eikon and Bloomberg.

Note. Aggregate ETF trades combine trades in the same new issue across ETFs in the sample, first across all new issues and then those in bonds issued by US companies in USD. The average combined share of new issue demand is then reported, comparing carbon-intensive and non-carbon-intensive issues according to TRBC activity. The average size of new bonds issued is then also compared across carbon-intensive and non-carbon-intensive sectors. 
Appendix D - ETF Share of Demand by Sector

\begin{tabular}{|l|cc|cc|}
\hline \multirow{2}{*}{} & \multicolumn{2}{|c|}{ IG } & \multicolumn{2}{c|}{ HY } \\
\cline { 2 - 5 } & Prop of NI & Frequency & Prop of NI & Frequency \\
\hline Communication Services & $0.65 \%$ & $7.73 \%$ & $1.24 \%$ & $12.95 \%$ \\
Consumer Discretionary & $0.49 \%$ & $6.75 \%$ & $1.33 \%$ & $11.51 \%$ \\
Consumer Staples & $0.59 \%$ & $6.39 \%$ & $1.05 \%$ & $2.88 \%$ \\
Energy & $0.49 \%$ & $5.15 \%$ & $1.74 \%$ & $11.97 \%$ \\
Financials & $0.75 \%$ & $35.71 \%$ & $1.21 \%$ & $23.54 \%$ \\
Health Care & $0.49 \%$ & $8.41 \%$ & $1.23 \%$ & $6.08 \%$ \\
Industrials & $0.51 \%$ & $10.16 \%$ & $1.20 \%$ & $14.13 \%$ \\
Information Technology & $0.61 \%$ & $4.09 \%$ & $1.11 \%$ & $1.57 \%$ \\
Materials & $0.65 \%$ & $1.51 \%$ & $1.19 \%$ & $5.69 \%$ \\
Real Estate & $0.50 \%$ & $1.75 \%$ & $1.08 \%$ & $5.23 \%$ \\
Utilities & $0.61 \%$ & $12.36 \%$ & $1.58 \%$ & $4.45 \%$ \\
\hline
\end{tabular}

Source. Data from Eikon and Bloomberg.

Note. Trades in the same new issue across ETFs in the sample are combined to calculate the proportion of primary market demand from ETFs in the sample. The average share of demand is shown by industry under "Prop of NI". In the next column, "Frequency" shows the proportion of new issues in our sample by industry.

Appendix E - Distribution of Primary Market Trades by Day of the Month

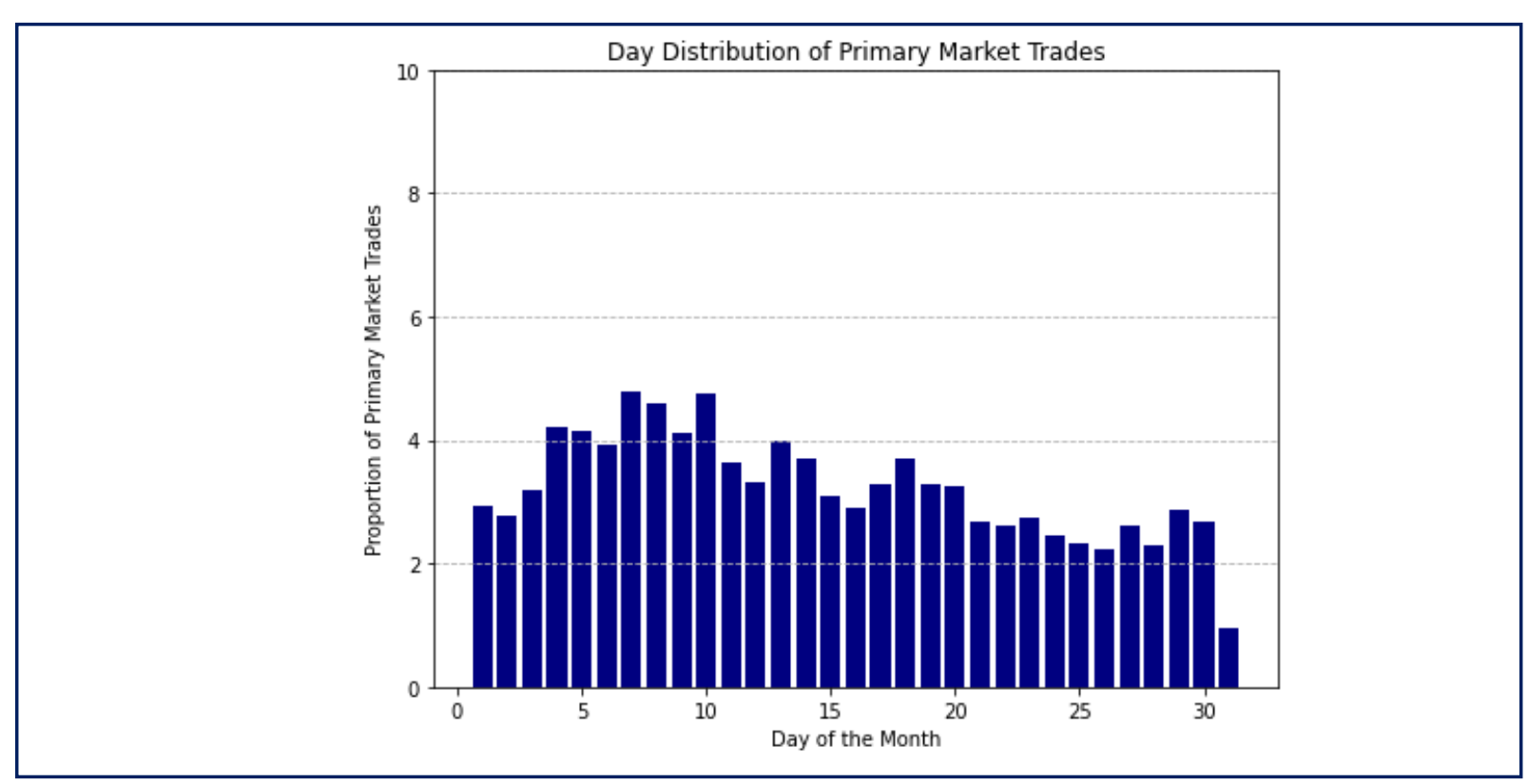

Source. Data from Eikon and Bloomberg. 


\section{Notes}

1. The Net-Zero Asset Owners Alliance include "Financing Transition Targets" but without a quantitative progress target.

2. A fall in equity prices can also reduce the ability of a company to achieve growth through M\&A.

3. The three ETFs that are not covered by this paper include VanEck Vectors Fallen Angel High Yield Bond ETF that covers only downgraded investment grade bonds. The other two ETFs are Vanguard Intermediate-Term Corporate Bond ETF and Vanguard Short-Term Corporate Bond ETF. These ETFs only disclose monthly holdings and are therefore not used.

\section{Declaration of Conflicting Interests}

None. There are also no sources of funding to declare. 


\section{References}

Aber, J. W., \& Li, D. (2009). Price volatility and tracking ability of ETFs. Journal of Asset Management, 10, 210-221. https://doi.org/10.1057/jam.2009.13

Advisory Group on Finance for the UK's Climate Change Committee. (2020). The Road to Net-Zero Finance.

Anadu, K., Kruttli, M., McCabe, P., \& Osambela, E. (2020). The Shift from Active to Passive Investing: Risks to Financial Stability? Financial Analysts Journal, 76(4), 23-39. https://doi.org/10.1080/0015198X.2020.1779498

Ansar, A., Caldecott, B., \& Tilbury, J. (2013). Stranded assets and the fossil fuel divestment campaign: what does divestment mean for the valuation of fossil fuel assets? Stranded Assets Programme, Smith School of Enterprise and the Environment, University of Oxford.

Baker, M. P., Stein, J. C., \& Wurgler, J. A. (2003). When Does the Market Matter? Stock Prices and the Investment of Equity-Dependent Firms. The Quarterly Journal of Economics, 118(3), 969-1105. https://doi.org/10.1162/00335530360698478

Beltratti, A. (2005). Capital market equilibrium with externalities, production and heterogeneous agents. Journal of Banking and Finance, 29(12), 3061-3073. https://doi.org/10.1016/j.jbankfin.2004.11.004

Bessembinder, H., Jacobsen, S., Maxwell, W., \& Venkataraman, K. (2020). Syndicate Structure, Primary Allocations, and Secondary Market Outcomes in Corporate Bond Offerings. SMU Cox School of Business Research Paper No. 20-04. https://doi.org/10.2139/ssrn.3611056

BlackRock. (2021). Getting ahead of the curve. https://www.ishares.com/us/literature/whitepaper/index-your-bonds-en-us.pdf

Boermans, M. A., \& Galema, R. (2019). Are pension funds actively decarbonizing their portfolios? Ecological Economics, 161, 50-60. https://doi.org/10.1016/j.ecolecon.2019.03.008

Boyarchenko, N., Kovner, A., \& Shachar, O. (2020). It's What You Say and What You Buy: A Holistic Evaluation of the Corporate Credit Facilities. Federal Reserve Bank of New York Staff Reports, 935. https://doi.org/10.2139/ssrn.3654390

Brest, P., \& Born, K. (2013). When Can Impact Investing Create Real Impact? Stanford Social Innovation Review. www.ssireview.org

Brest, P., Gilson, R. J., \& Wolfson, M. A. (2018). How Investors Can (and Can't) Create Social Value. SSRN Electronic Journal, March. https://doi.org/10.2139/ssrn.3150347

Caldecott, B. (2019). How green and sustainable is China's Belt and Road Initiative? 
https://www.libf.ac.uk/news-and-insights/news/detail/2019/08/19/how-greenand-sustainable-is-china-s-belt-and-road-initiative

Caldecott, B. (2020). Climate risk management (CRM) and how it relates to achieving alignment with climate outcomes (ACO). https://doi.org/10.1080/20430795.2020.1848142

Caldecott, B., Harnett, E., Clark, A., \& Koskelo, K. (2021). Sustainable Finance and Transmission Mechanisms to the Real Economy. Forthcoming.

CDP, \& WWF. (2020). Temperature Rating Methodology: A Temperature Rating Method for Targets, Corporates, and Portfolios. 0-37.

Chang, Y. C., Hong, H., \& Liskovich, I. (2015). Regression discontinuity and the price effects of stock market indexing. In Review of Financial Studies (Vol. 28, Issue 1). https://doi.org/10.1093/rfs/hhu041

Charoenwong, B., Morck, R., \& Wiwattanakantang, Y. (2020). Bank of Japan Equity Purchases: The (Non-)Effects of Extreme Quantitative Easing. Review of Finance, rfaa029. https://doi.org/10.1093/rof/rfaa029

Chenet, H., Ryan-Collins, J., \& van Lerven, F. (2019). Climate-Related Financial Policy in a World of Radical Uncertainty: Towards a Precautionary Approach. UCL Institute for Innovation and Public Purpose, Working Paper Series (IIPP WP 2019-13). https://doi.org/10.2139/ssrn.3520224

Christophers, B. (2017). Climate Change and Financial Instability: Risk Disclosure and the Problematics of Neoliberal Governance. Annals of the American Association of Geographers, 107(5), 1108-1127. https://doi.org/10.1080/24694452.2017.1293502

Cojoianu, T. F., Ascui, F., Clark, G. L., Hoepner, A. G. F., \& Wójcik, D. (2020). Does the fossil fuel divestment movement impact new oil and gas fundraising? Journal Of Economic Geography, 1-24. https://doi.org/10.1093/jeg/lbaa027

Cullen, J. (2018). After "HLEG": EU Banks, Climate Change Abatement and the Precautionary Principle. Cambridge Yearbook of European Legal Studies, 20(August 2018), 61-87. https://doi.org/10.1017/cel.2018.7

Curtin, J., Mclnerney, C., Ó Gallachóir, B., Hickey, C., Deane, P., \& Deeney, P. (2019). Quantifying stranding risk for fossil fuel assets and implications for renewable energy investment: A review of the literature. In Renewable and Sustainable Energy Reviews (Vol. 116, p. 109402). Elsevier Ltd. https://doi.org/10.1016/j.rser.2019.109402

D'Amico, S., Kurakula, V., \& Lee, S. (2020). Impacts of the Fed Corporate Credit Facilities through the Lenses of ETFs and CDX. Federal Reserve Bank of Chicago Working Paper 2020-14. https://doi.org/10.21033/wp-2020-14

Dannhauser, C. D. (2017). The impact of innovation: Evidence from corporate bond exchange-traded funds (ETFs). Journal of Financial Economics, 125(3), 537- 


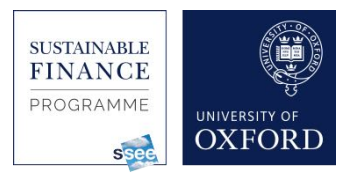

560. https://doi.org/10.1016/j.jfineco.2017.06.002

Dathan, M., \& Davydenko, S. A. (2018). Debt Issuance in the Era of Passive Investment. SSRN Electronic Journal, 2020.

https://doi.org/10.2139/ssrn.3152612

De Jong, M., \& Nguyen, A. (2016). Weathered for climate risk: A bond investment proposition. Financial Analysts Journal, 72(3), 34-39. https://doi.org/10.2469/faj.v72.n3.2

Derrien, F. (2005). IPO pricing in "hot" market conditions: Who leaves money on the table? Journal of Finance, 60(1), 487-521. https://doi.org/10.1111/j.15406261.2005.00736.x

DivestInvest. (2018). How to DivestInvest. A guide for Institutional Investors.

Drobetz, W., El Ghoul, S., Guedhami, O., \& Janzen, M. (2018). Policy uncertainty, investment, and the cost of capital. Journal of Financial Stability, 39, 28-45. https://doi.org/10.1016/j.jfs.2018.08.005

Erickson, P., Down, A., Lazarus, M., \& Koplow, D. (2017). Effect of subsidies to fossil fuel companies on United States crude oil production. Nature Energy, 2(11), 891-898. https://doi.org/10.1038/s41560-017-0009-8

Regulation (EU) 2020/852 of the European Parliament and of the Council of 18 June 2020 on the establishment of a framework to facilitate sustainable investment, and amending Regulation (EU) 2019/2088 (Text with EEA relevance), (2020). http://data.europa.eu/eli/reg/2020/852/oj

European Commission. (2020). Taxonomy : Final report of the Technical Expert Group.

Farmer, J. D., Hepburn, C., Ives, M. C., Hale, T., Wetzer, T., Mealy, P., Rafaty, R., Srivastav, S., \& Way, R. (2019). Sensitive intervention points in the post-carbon transition. Science, 364(6436), 132 LP - 134.

https://doi.org/10.1126/science.aaw7287

Fattouh, B., Rahmatallah, P., \& West, R. (2019). Energy Transition Uncertainty andthe Implications of Change in the Risk Preferences of Fossil Fuel Investors Insight.

Federal Reserve. (2020). Secondary Market Corporate Credit Facility. Federal Reserve Bank. https://www.federalreserve.gov/monetarypolicy/smccf.htm

Federal Reserve. (2021). SMCCF Transaction-specific disclosures (XLSX) (January 11, 2021). https://www.federalreserve.gov/publications/files/smccf-transactionspecific-disclosures-01-11-21.xIsx

Fossil Free. (2021). Divestment Commitments. https://gofossilfree.org/divestment/commitments/

Frank, M. Z., \& Shen, T. (2016). Investment and the weighted average cost of 
capital. Journal of Financial Economics, 119(2), 300-315.

https://doi.org/10.1016/j.jfineco.2015.09.001

Fridson, M. S., \& Gao, Y. (1996). Primary versus secondary pricing of high-yield bonds. Financial Analysts Journal, 52(3), 20-27.

https://doi.org/10.2469/faj.v52.n3.1992

Gilchrist, S., \& Zakrajsek, E. (2007). Investment and the Cost of Capital: New Evidence from the Corporate Bond Market. NBER Working Paper.

Gilchrist, S., \& Zakrajšek, E. (2012). Credit spreads and business cycle fluctuations. American Economic Review, 102(4), 1692-1720. https://doi.org/10.1257/aer.102.4.1692

Goldstein, M. A., Hotchkiss, E. S., \& Pedersen, D. J. (2019). Secondary Market Liquidity and Primary Market Pricing of Corporate Bonds. Journal of Risk and Financial Management, 12(2), 86. https://doi.org/10.3390/jrfm12020086

Gollier, C., \& Pouget, S. (2014). “The 'Washing Machine':Investment Strategies and Corporate Behavior with Socially Responsible Investors." 4(3), 89-93.

Gonedes, N. J. (1975). Information-Production and Capital Market Equilibrium. The Journal of Finance, 30(3), 841-864.

Halling, M., Yu, J., \& Zechner, J. (2020). How did COVID-19 affect firms' access to public capital markets? Review of Corporate Finance Studies, 9(3), 501-533. https://doi.org/10.1093/rcfs/cfaa008

Heinkel, R., Kraus, A., \& Zechner, J. (2001). The Effect of Green Investment on Corporate Behavior. The Journal of Financial and Quantitative Analysis, 36(4), 431-449. https://www.jstor.org/stable/

HM Treasury. (2020). A Roadmap towards mandatory climate-related disclosures. https://www.gov.uk/government/publications/uk-joint-regulator-and-governmenttcfd-taskforce-interim-report-and-roadmap

Hoepner, A. G. F., \& Schneider, F. I. (2020). The Science of Impact: Engage in Equities, Deny Debt!

https://www.transitionpathwayinitiative.org/publications/46?type=NewsArticle

Hunt, C., \& Weber, O. (2019). Fossil Fuel Divestment Strategies: Financial and Carbon-Related Consequences. Organization \& Environment, 32(1), 41-61. https://doi.org/10.1177/1086026618773985

ICI. (2014). Understanding Exchange-Traded Funds: How ETFs Work. In Ici Research Perspective (Vol. 20, Issue 5). www.ici.org/pdf/per20-05.pdf

IIGCC. (2020). Net Zero Investment Framework for Consultation. www.iigcc.org

Intintoli, V. J., Jategaonkar, S. P., \& Kahle, K. M. (2014). The Effect of Demand for Shares on the Timing and Underpricing of Seasoned Equity Offers. Financial Management, 43(1), 61-86. https://doi.org/10.1111/fima.12020 


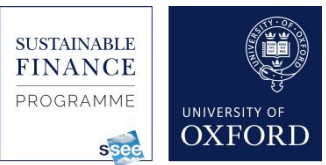

IPCC. (2018). IPCC Special Report 1.5 - Summary for Policymakers. In IPCC.

Jahnke, P. (2019). Holders of Last Resort: The Role of Index Funds and Index Providers in Divestment and Climate Change. SSRN Electronic Journal, March, 1-22. https://doi.org/10.2139/ssrn.3314906

Kargar, M., Lester, B., Lindsay, D., Liu, S., Weill, P.-O., \& Zúñiga, D. (2020). Corporate Bond Liquidity During the COVID-19 Crisis. National Bureau of Economic Research, 27355. https://doi.org/10.3386/w27355

Kölbel, J. F., Heeb, F., Paetzold, F., \& Busch, T. (2020). Can Sustainable Investing Save the World? Reviewing the Mechanisms of Investor Impact. Organization and Environment, 33(4), 554-574. https://doi.org/10.1177/1086026620919202

Lin, X., Wang, C., Wang, N., \& Yang, J. (2018). Investment, Tobin's q, and interest rates. Journal of Financial Economics, 130(3), 620-640. https://doi.org/10.1016/j.jineco.2017.05.013

Lindvall, J. R. (1977). New Issue Corporate Bonds, Seasoned Market Efficiency and Yield Spreads. 32(4), 1057-1067.

Luo, H. A., \& Balvers, R. J. (2017). Social Screens and Systematic Investor Boycott Risk. JOURNAL OF FINANCIAL AND QUANTITATIVE ANALYSIS, 52(1), 365399. https://doi.org/10.1017/S0022109016000910

Mazzucato, M. (2016). From market fixing to market-creating: a new framework for innovation policy. Industry and Innovation, 23(2), 140-156. https://doi.org/10.1080/13662716.2016.1146124

Mercer. (2020). European Asset Allocation Insights 2020.

Merton, R. C. (1987). A Simple Model of Capital Market Equilibrium with Incomplete Information. The Journal of Finance, 42(3), 483-510. https://doi.org/10.1111/j.1540-6261.1987.tb04565.x

Mésonnier, J., \& Nguyen, B. (2021). Showing off Cleaner Hands: Mandatory Climate-Related Disclosure by Financial Institutions and the Financing of Fossil Energy by Jean-Stéphane Mésonnier, Benoît Nguyen :: SSRN. January. https://papers.ssrn.com/sol3/papers.cfm?abstract_id=3733781

Mola, S., \& Loughran, T. (2004). Discounting and Clustering in Seasoned Equity Offering Prices. 39(1), 1-23.

Monasterolo, I., Battiston, S., Janetos, A. C., \& Zheng, Z. (2017). Vulnerable yet relevant: the two dimensions of climate-related financial disclosure. Climatic Change, 145, 495-507. https://doi.org/10.1007/s10584-017-2095-9

Morch, R., \& Yang, F. (2001). The Mysterious Growing Value of S\&P 500 Membership. In NBER Working Papers No 8654. https://doi.org/10.3386/w8654

Morningstar. (2020). Passive Sustainable Funds: The Global Landscape 2020. https://www.morningstar.hk/hk/news/205231/passive-sustainable-funds-the- 
global-landscape-2020.aspx

O'Hara, M., \& Zhou, X. (Alex). (2020). Anatomy of a Liquidity Crisis: Corporate Bonds in the COVID-19 Crisis. Journal of Financial Economics (JFE), Forthcoming. https://doi.org/10.2139/ssrn.3615155

Ondraczek, J., Komendantova, N., \& Patt, A. (2015). WACC the dog: The effect of financing costs on the levelized cost of solar PV power. Renewable Energy, 75, 888-898. https://doi.org/10.1016/j.renene.2014.10.053

Ottonello, G. (2018). The Impact of Benchmarking in Fixed Income Funds.

PCAF. (2020). The Global GHG Accounting and Reporting Standard for the Financial Industry.

Quigley, E. (2019). Universal Ownership in the Anthropocene. SSRN Electronic Journal, 1-39. https://doi.org/10.2139/ssrn.3457205

Quigley, E., Bugden, E., \& Odgers, A. (2020). Divestment: Advantages and Disadvantages for the University of Cambridge.

https://www.cam.ac.uk/system/files/sm6_divestment_report.pdf

Ritchie, J., \& Dowlatabadi, H. (2014). Understanding the shadow impacts of investment and divestment decisions: Adapting economic input-output models to calculate biophysical factors of financial returns.

https://doi.org/10.1016/j.ecolecon.2014.07.005

Rosane, P., Micale, V., Naran, B., Rosane, P., Wetherbee, C., \& Falconer, A. (2020). A Proposed Method for Measuring Paris Alignment of New Investment. December.

Schmidt, T. S. (2014). Low-carbon investment risks and de-risking. 4(April), 237239.

Scholtens, B. (2006). Finance as a driver of corporate social responsibility. Journal of Business Ethics, 68(1), 19-33. https://doi.org/10.1007/s10551-006-9037-1

Schroders. (2019). Institutional Investor Study 2019.

SEC. (2014). Precidian ETFs Trust, et al.; Notice of Application.

SIFMA. (2021). SIFMA Research Quarterly - 4Q20.

State Street Global Advisors. (2021). Fixed Income ETF Mechanics: Understanding the Processes of Creation, Redemption and Basketing.

https://www.ssga.com/library-content/story/general/etf/emea/spdr-fixed-incomeetf-mechanics.pdf

Task Force on Climate-related Fiancial Disclosures. (2017). Recommendations of the Task Force on Climate-related Financial Disclosures. https://www.fsbtcfd.org/wp-content/uploads/2017/06/FINAL-2017-TCFD-Report-11052018.pdf

TCFD. (2020). Task Force on Climate-related Financial Disclosures: Forward- 
Looking Financial Sector Metrics Consultation. https://www.unepfi.org/climatechange/tcfd/

Thomä, J., \& Chenet, H. (2017). Transition risks and market failure: a theoretical discourse on why financial models and economic agents may misprice risk related to the transition to a low-carbon economy. Journal of Sustainable Finance \& Investment, 7(1), 82-98.

https://doi.org/10.1080/20430795.2016.1204847

Turner, G. (2018). The implications of passive investing for securities markets. BIS Quarterly Review, March, 113-131.

UNEP FI. (2020). Inaugural 2025 Target Setting Protocol.

UNFCCC. (2021). New Financial Alliance for Net Zero Emissions Launches. https://unfccc.int/news/new-financial-alliance-for-net-zero-emissions-launches

United Nations. (2015). Paris Agreement.

Unruh, G. C. (2000). Understanding carbon lock-in.

Urban, M. A., \& Wójcik, D. (2019). Dirty banking: Probing the gap in sustainable finance. Sustainability (Switzerland), 11(6). https://doi.org/10.3390/su11061745

Vanguard. (2020). Fixed income myths, part 2: "Bond indexing is simple." https://www.vanguard.nl/portal/site/institutional/nl/en/articles/research-andcommentary/portfolio-construction/fixed-income-indexing-myths-pt2-bondindexing 